な検討を行ったので報告する。

〔結果】 X線フィルムをディシタル化したデータの予 測䛊差を前值予測および行列予測について求め, 予測愦 差をハフマン符号化およびワイル符号を基汸考案した規 則性のある可变長符号により符号化する計算機シミュレ ーションを行った。 行列予測を用いた方が前值予測に比 べ高圧縮が期待できる。また，行列予測を用いた場合， 2 つ0可変長符号化により，平均で50\%以下に圧縮でき るととが解った.

383. DSA 撮影時におけるボーラスについての検討 浜松医科大学附属病院放射線部

○坂本㥲次・竹田浩康 杉江義男・金子昌生

DSA 撮影において画質に影響をおるよ゙す因子として は数多くあるが, なかでも TV カメラ系における撮像管 のダイナミック，レンジが良好なイメージを得るために は問題となる. 現在, プランビコンチューブを使用して いるが，ハレーションを最小限に少なくする事が不可矢 である。

今回，われわれは八レーション防山用としてのボーラ スについて, 取り扱いの簡便さおよび材質等, 検討を加 えた結果，小麦粉粘土において良好な絬果が得られた。

384. DSA による心機能解析

神戸大学医学部附属病院中央放射線部 ○松永 登・今井方丈・古東正宜 岡山貴宣・小寺滋子 神戸大学医学部放射線医学教室 杉村和朗

〔目的〕循環器領域における画像情報は機能情報が重 要であり, 静注法による左室造影像の機能解析と是量化 を試みると共に, シネ画像とのデータの対比を行った。

〔方法】DAR-100により OMI 対象资患とした Cardiac Digital Subtraction Angiography 施行し, VDR の video 信号を既設の左室機能解析装置 LVV-100 亿入力し左室容積, EF 值, wall motion 等の解析を行っ た。

〔結果〕1. 機能解析システムを有しないDR 装置で 每上記の方法により左室機能の定量化が可能である。 2 . シネデータとの対比に関し, EDV, ESV は幾らかの䛊差 を生じるが EF は近似值を示し wall motion は好結果を 得た. 3. 画質の改善には frame memory の応用が有效 であった。

$385, \mathrm{X}$ 線写真の MTF による画像処理

東京都立㟝療放射線専門学校
○細淵安弘

〔目的〕本研究はデシタル化システムを用いてすべて の周波数に一様な応答を示す理想的な MTFをもつX線 写真像をコンピュータにより再構成したので報告する.

〔結果]原画像は直接撮影方式のMTF 仮定した胸 部X線間接像で画像処理を行っていない.4 枚の処理画 像はそれぞれ $2 ， 4 ， 8 ， 16$ サイクルまで一様な応答を もつMTFに対応したもので，2４4，8，16サイクル まで MTF 值が 1 であり, 以下一様に 16 サイクルまで MTF 值が0に低下したものである．2，4サイクルの 画像は原画像と比較すると画像のディテールが改善され ているが，4サイクルではわずかにノイズが強調されて いる.8，16サイクルはノイズ多く，画像の改善が消え ている。

386. ピークホールド式メモリの外科用 $\mathrm{X}$ 線 TV 装置へ の応用

市立舞鶴市民病院放射線科

○伊藤陽二

(株)島津製作所医用技術部

橋詰辰夫・駒井德蔵・宅間義洋

從来, 胆道系手術の術中撮影には回晾用コンデンサ装 置を使用しており，画質の面ではたいへん優れていた。 しかし，撮影結果を得るまでの時間が長く，しかも造影撮 影のため, 経験と感に頼らなければならないという久点 があった。.今回，乙れらの久点を無くすととを目的とし て，ピークホールド式メモリ付外科用X線 TV 装置の使 用を試みた。結果は動的情報をりアルタイムで得ること ができ，タイミングのよい診断に必要な静上画像が得ら れた. 静止画像はピークホールド処理により, 量子ノイ ズが低減され，解像力がよいため，胆石・気泡・奇形の 判定に有用であった。また，撮影結果を待たずに手術が でき，手術時間は大幅に短縮するととができた。

\section{7．DSA を用いた心筋灌流状態の観察の試み}

国立循環器病センター

○香川雅昭・橋本時弘 松井泰伸・巣組一男

DSA (Digital Subtraction Angiography) の利点を最 大限に生かし虚血性心笑患における灌流状態を観察する ことを試み，乙の方法が臨床的に有意義であるか基礎的 検討を行った。

〔方法〕虚血性心疾患45例，正常例 5 例老用い，心筋 部位と捱野飞 back ground とし ROI を設定し, 各 frame 毎に補正し, time-density curveを求めた。

〔結果・考察】心筋梗塞部において, 正常例に対して, 